\title{
THE INFLUENCE OF DISSATISFIED TOURISTS' NON-BEHAVIORAL APPROACH ON OVERALL VISIT SATISFACTION: A STUDY ON MALAYSIAN DOMESTIC TOURISTS
}

\author{
Ataul Karim PATWARY* \\ Universiti Utara Malaysia, School of Tourism, Hospitality and Event Management, 06010 UUM, Sintok, Kedah, Malaysia, e-mail: raselataul@gmail.com \\ Hamimi OMAR \\ Universiti Utara Malaysia, School of Tourism, Hospitality and Event Management, 06010 UUM, Sintok, Kedah, Malaysia, e-mail: hamimi@uum.edu.my
}

\begin{abstract}
Citation: Patwary, A.K. \& Omar, H. (2020). THE INFLUENCE OF DISSATISFIED TOURISTS' NON-BEHAVIORAL APPROACH ON OVERALL VISIT SATISFACTION: A STUDY ON MALAYSIAN DOMESTIC TOURISTS. GeoJournal of Tourism and Geosites, 32(4), 13881393. https://doi.org/10.30892/gtg.32429-585
\end{abstract}

\begin{abstract}
Providing good quality of service is most basic attribute of the service industry, including tourism. Complaints by tourists actually provide opportunities for destination or business to recover from the service failures, and when the complaints are handled satisfactorily, destination or business may win tourists back. Therefore, this study aims to explore how complaint constraints influence on tourists' overall satisfaction level. In order to achieve the objectives, this study used a quantitative approach using PLS-SEM. This study revealed that overall tourists' satisfaction is influenced by limited time, unfamiliarity, limited communication, limited involvement, and positive holiday mood.
\end{abstract}

Key words: Tourists' Satisfaction, Complaint Constraints, Domestic Tourism, PLS-SEM, Tourism, Malaysia.

$* * * * *$

\section{INTRODUCTION}

Tourists do not expect any dissatisfied experiences during their visit as they pay good money and expect the same with experience. Tourists today demand a high quality of service, and their level of tolerance becomes very low when they experience low quality of products or poor services (Su and Bowen, 2001). According to Lam and Tang (2003), when the providers are not able to satisfy them, tourists might express their dissatisfaction by complaining. Thus, customer complaints are an inevitable part of the tourism industry. Nyer (2000) reveals that marketers are in agreement that tourists' complaints are defined as fruitful sources of information which will assist marketers in recognizing the origin of dissatisfaction. Those tourists are encouraged to make a complaint would contribute on the greater increase of customer satisfaction and product evaluation, in comparison with those consumers are not willing to make complain. Complaints by tourists provide opportunities for destination or business to recover from the service failures, and when the complaints are handled satisfactorily, destination or business may win tourists back. Ultimately this may encourage repeat, or even, loyal tourists (Ekiz and $\mathrm{Au}, 2011)$. On the other hand, when tourists choose not to make a complaint, destination, or business will not be able to make amendment or improvement and loses its competitiveness in the market (ibid, 2009). According to Hedrick et al. (2007), only a low per cent of dissatisfied tourists tends to complain about their disappointing experiences. This is supported by Best and Andrease n (1977), stated that less than $50 \%$ of the dissatisfied tourists directly complain about their problems to the service provider.

Houcutt, Mowen and Chakraborty (1997), further explained that while dissatisfaction occurs, even though tourists do not complain, sometimes they tend to come back to the same service provider or destination. The authors added that this situation, however, happens only if tourists do not have any other options in destination or hotel choice. In many instances, however, tourists would do the opposite. The study revealed that $96 \%$ of dissatisfied tourists are found to ignore that particular destination (Stephens and Gwinner, 1998). Only a small percentage of tourist make a complaint about their dissatisfying experience and approximately two-thirds of them do not make any complaint (Richins, 1982; Day and Ash, 1979). Albrecht and Zemke (1996) revealed that only 5\% of dissatisfied tourists give complaints to the correspondent body. According to Furlong (1993), dissatisfied tourists usually choose not to complain about their negative experiences because their expectation is very low on getting positive feedback or satisfactory result.

The same sentiment was also given by Badghish, Stanton and Hu (2015). Thus, implying that making complaints is wasting tourists' time and effort (Day et al., 1981). However, the majority of dissatisfied tourists usually choose not to complain about their negative experiences (Christiansen and Snepenger, 2002; Cohen, 2004). Tourists' silence or not complaining could be more precarious than voicing their problems or sharing their negative experiences. Hence, understanding why tourists do not complain has become a crucial matter. Thus, it leaves a gap for the researcher to fill. Therefore, this study is conducted to understand the influence of complaint constraints on overall satisfaction among Malaysian tourists when dissatisfaction occurs with hotel services.

\section{LITERATURE REVIEW}

\section{Tourists complaint constraints}

Limited time

Morello (2004) claimed that there are two categories of time: firstly, the clock time or objective time. Though Allaman et al. (2013) discussed the category of the time in their study is only clock time. According to Treisman (2013:2), the clock time can measure with definite terms, such as seconds, minutes and hours. The mental time or personal time is measured by people's preferences or their experiences in place of subjective measurement standards. People use the clock to manage the time, and that signifies the entire terms.

On the other hand, Knaap (1997) added, during the holiday, there must be a pre-determined time in terms of scheduling the activities during the tour, people are probable to miss track of their time. In this study, the concept of time used as the duration of time spent in a holiday destination. Previous literature of CCB explained that having not enough time or Limited Time is considered as one of the significant

\footnotetext{
${ }^{*}$ Corresponding author
} 
factors which can influence consumers' complaint behaviour (Gronhaug and Zaltman, 1981; Swanson and Kelly, 2001; TARP, 1999). According to Swanson and Kelly (2001), time limitation of tourists is an important aspect has effects to the service industry, on that place, the co-existence of consumer and service providers are generally needed. Chebat and Slusarczyk (2005) mentioned that timeliness as an essential requirement to solve the problem. Time goes into consideration while dissatisfied consumers seek recovery through complaining.

\section{Unfamiliarity}

Soderlund (2002) defined the familiarity as the number of product-related involvements accumulated by the consumer. Day and Landon (1976, p.181) argued that "...the less knowledgeable [familiar in this instance] consumer will be less able to judge product performance and evaluate the goods and services as he consumes...also he will be unfamiliar with procedures for seek ing redress and in registering complaints" (p.5). They added that geographical factors and ethnic factors could be probable reasons for discrepancy of customers' knowledge on that product (Day and Landon, 1976). In another way, the consumers may get more confidence in the familiar environment. Thus it helps in expressing their satisfaction and/or dissatisfaction clearly.

Soderlund (2002) explained that familiarity with the products can bring more ease in the process of purchasing and "provides the customer with a different frame of references for evaluations compared to a low level of familiarity" (p.863). The author further addressed that the tourists with high familiarity intend more on accepting the extreme; it could be high and low-performance functions, even others too. The possible meaning of 'low-performance event' is the high level of service failures (Soderlund, 2002).

\section{Limited communication}

Communication is an important element of human nature and particularly significant for individuals' regular social interaction. The definition of communication is given by Schiffman and Kanuk (2004) as "...The transmission of a message from a sender to a re ceiver via a medium, or channel, of transmission" (p.293). Auditory is considered as a medium to convey the communication, these are singing or speaking, or through physical means which are sign languages, touching, or by making eye contact.

The form of communication is classified as verbal communication (communicating through using the language, word, speaking and sound) and non-verbal communication. Verbal communication, in the form of using language, plays a major part in the process of human communication. Bonvillain (2003) defined language as “...a communicative system consisting of formal units that are integrated by processes of combining components of sound, structure and meaning" (p.7).

\section{Limited involvement}

In consumer behaviour research area, 'Involvement' has received vast attention. According to Sharma et al. (2010), when a consumer has more involvement with a good, service, or in a situation of consuming the products, the more likely this consumer will tend to afford resources such as money, effort and time to voice out a complaint or seeking for redress for a dissatisfactory experience.

Mittal and Lee (1989) quoted that "...involvement has played an increasingly important role in explaining consumer behaviour (and has a significant relation with) extensiveness of the decision-making process and on-going product-related behaviour such as spreading word-of-mouth to peers". Involvement requires consumers to spend extra psychological and physical effort to understand and be part of the service offered (p.363). Tourism literature reflects that there is a comparatively smaller quantity of researchers who investigated the probable effects of Limited Involvement on consumers' purchasing behaviour, except Havitz and Dimanche (1999) and Altinay (1994). Cai et al., (2004) reported that, purchasing decision of tourists' involvement is based on information prefer ences context of tourists'.

The conclusion is made as that involvement, and Limited Involvement plays noteworthy roles in the 'pre-trip stage' of tourists' decision-making process; the statement is supported by (Cai et al., 2004).

\section{Positive holiday mood}

Iso-Ahola (1982) noted that the tourists' mood should be taken into consideration when analyzing tourists' behaviours. Liljander and Mattsson (2002) claimed that to understand tourists' behaviour, the psychological approach can play a vital role. According to Voase (1995), escaping from the routine is considered as one of the most basic psychological motivations behind travelling. Mill (1990) has provided the same statement that people are required to enjoy at least several days' holiday to wind down from their daily activities and to get some mental relaxation. Cohen (2004) stated that people travel to a different place to avoid common regular everyday activities, escape duties imposed upon them, get rid of tension within their life, search for recreation which is a no-work, no care, and no-thrift situation.

Similarly, most tourists think in their mind and convince themselves that holiday will bring joy and positive experience (Wood and House, 1991). Equally, leisure tourists always look to get a hassle-free travel experience, while they tend to think positively despite the difficulties they have experienced during the journey (Pearce, 1982). Therefore, "...driving pleasure from the trip is a central and noninstrumental concern for the tourist" and to do so, they "...enjoy taking it easy" (Suvantola and Gibson, 1992). This might happen due to tourists' temporary mode while visiting a place (Hosany and Gilbert, 2010; Suvantola, 2002).

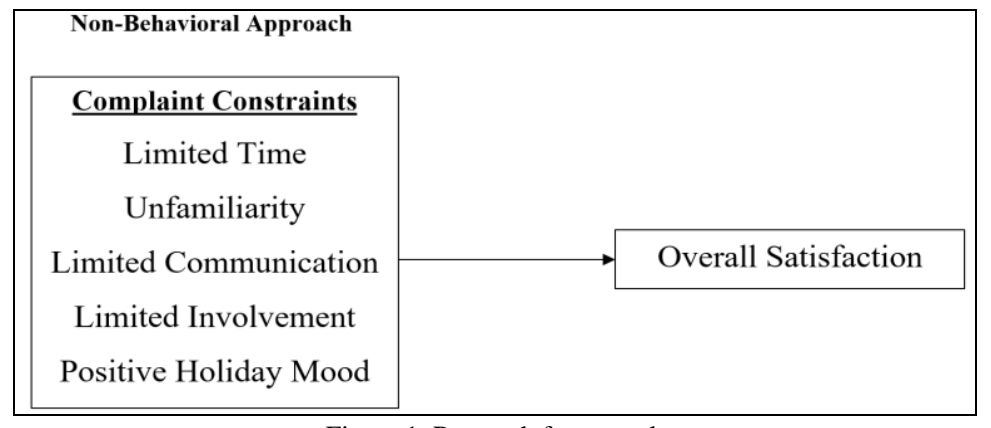

Figure 1. Research framework

\section{Overall tourists satisfaction}

Customer satisfaction has been defined as the combination of tourists' expectation prior to travel and their subsequent experiences (Baker and Crompton, 2000). By comparison, quality refers to the service operation's 'output', i.e., the attributes of the product that are 
primarily under the control of the operation (Crompton and Love, 1995). According to Oliver (1980), dissatisfaction occurs once the performance level is unable to meet a certain level of expectations. The concept of consumer satisfaction was widely debated in consumer behaviour literature during the 1980s and 1990s (Oliver, 1999). This debate has had an important resonance among tou rism researchers, both conceptually and methodologically (Jamal et al., 2011; Kozak, 2001; Hassan et al., 2020). Due to multidimensional nature of tourism services (Maunier and Camelis, 2013), consumers always seek experiences that will satisfy their different needs simultaneously, while most of the needs are often effective based (Laing et al., 2014). Satisfaction is depending on the perceived difference between consumer's expectations and employee's perceived performance. Satisfaction is the individual's positive sense of experience (Rust and Oliver, 1994). It is normally measured before and after the trip in the tourism context. For instance, favourable feelings of tourists after a trip perceived as satisfaction, while experiencing an unfavourable feeling dominates the perception of dissatisfaction (Reisinger and Turner, 2003).

Based on the above discussion, this study proposed these hypotheses:

H1: Limited-Time has a significant influence on Overall Satisfaction of the domestic tourists in Malaysia

H2: Unfamiliarity has a significant influence on Overall Satisfaction of the domestic tourists in Malaysia

H3: Limited Communication has a significant influence on Overall Satisfaction of the domestic tourists in Malaysia

H4: Limited Involvement has a significant influence on Overall Satisfaction of the domestic tourists in Malaysia

H5: Positive Holiday Mood has a significant influence on Overall Satisfaction of the domestic tourists in Malaysia

\section{METHODOLOGY}

This is a quantitative study which seeks to investigate the influence of complaint constraints on tourists' overall visit satisfaction. In this research population defined as Malaysian tourists who have experienced dissatisfaction on hotel service during their visit. The number of domestic tourists in 2014 was 45,731,000 in overall Malaysia, and among them, 14\% stayed in the hotel during their trip. As this study focused on the hotel sector, the total number of tourists were staying in the hotel in 2014 is approximately 6, 402,340. According to the study of Bloemer et al. (2002), the percentage of dissatisfied consumers is $21.35 \%$, which is the population for this study. When the liberal assumption for the percentage of dissatisfied consumers counted following previous literature in approximately 20\%, so the population size was $1,280,468$, the researcher expected to get back 384 useable questionnaires from the respondents by agreeing with sampling table of Krejcie and Morgan, (1970) as they suggested, a sample size of 384 would be adequate for a population over 1 million. By using 384 as the target sample size, the true percentage in the whole population could fall within a positive or negative $5 \%$ range of the percentage obtained from the sample (Riddick and Russell, 1999). To get the information from different background, the researcher distributed the questionnaire to several places in the northern region. The researcher chose to use convenient sampling technique for distributing the questionnaires among respondents. The items comprised of tourists' complaint constraint upon their dissatisfying experiences, these items were adapted from Ekiz (2011). The items to measure overall visit satisfaction were adopted from Bhattacherjee (2001) and Oliver (1997).

\section{RESULTS AND DISCUSSION}

\section{Demographic information}

Respondents' socio-demographic information provided at a glance such as age groups, gender distribution, education levels, and monthly income. Among 381 respondents, 194 (50.9\%) are male and remaining 187 (49.1\%) are female. This study focused on Malaysian tourists, in terms of race, Malay (53.3\%), Chinese (26.8\%), Indian (16.5\%) and others (3.4\%). For the age groups, majority of them are $31-40$ years old (37.55\%) followed by $21-30(28.6 \%), 41-50(24.4 \%), 51-60$ years old $(8.7 \%)$ and 61 and above $(0.8 \%)$. For marital status, $62.6 \%$ of them are married, $35.4 \%$ are single, and $2.1 \%$ of them are widows.

The results of descriptive statistics for the ultimate variables are shown in the following table. According to Ahmmed (2014), for easy interpretation of the results of descriptive analysis, the range of five-point Likert scale is classified into three equal size classes, namely low, moderate and high. These are, values of lower than 2.33 [4/3+lowest value (1)] is treated as low; values of 3.67 [highest value (5)-4/3] are taken as high and values between these two extreme are treated as moderate.

Table 1. Descriptive statistics for dimensions of variables

\begin{tabular}{|l|c|c|}
\hline Dimensions (Variables) & Mean & SD \\
\hline Limited Time & 3.3998 & .79671 \\
\hline Unfamiliarity & 3.1820 & .83779 \\
\hline Limited Communication & 3.3333 & .75432 \\
\hline Limited Involvement & 3.2822 & .87271 \\
\hline Positive Holiday Mood & 3.3325 & .76606 \\
\hline
\end{tabular}

Note $\mathrm{SD}=$ Standard deviation

From the above table (Table 1) it is evident that mean values for Limited Time, Limited Communication, Unfamiliarity, Limited Involvement and Positive Holiday Mood fall into the range of 3.24 and 3.35. Most of the tourists did not complain due to Limited Time.

\section{Measurement model of the study}

For evaluating construct validity and reliability of the study variables, the researcher used measurement model assessment in Smart PLSSEM using an algorithm. Table 2 and Figure 1 below shows the results of the measurement model of this study. The outer loadings for the measurement items of the variables are in an acceptable range. For a limited time, outer loadings counted as LT1-0.876, LT2-0.889, LT30.857 and LT4-0.772. For limited communication, outer loadings found as Communi1-0.920, Communi 2-0.874 and Communi 3-0.758. For limited involvement, outer loadings are LI1-0.951 and LI2-0.951. Outer loadings for positive holiday mood are Mood1-0.887, Mood2-0.858 and Mood 3-669. For unfamiliarity, outer loadings counted as Unfami1-0.851, Unfami2-0.912, Unfami3-0.915 and Unfami 4-0.920. For overall satisfaction, loadings are counted as Satisfaction1-0.878, Satisfaction2-0.894, Satisfaction3-0.830 and Satisfaction 4-0.832.

Table 1 also shows the Average Values Extracted for each variable. Average Values Extracted (AVE) found as 0.722, 0.729, 0.904, 0.657, 0.810 and 0.738 for a limited time, limited communication, limited involvement, positive holiday mood, unfamiliarity, and overall satisfaction respectively. This study implemented two techniques for identifying the discriminant validity of the study, which are HeterotraitMonotrait Ratio (HTMT) and Fornell - Larcker Criterion. Table 3 and Table 4 show the results of Heterotrait-Monotrait Ratio (HTMT) and Fornell - Larcker Criterion, which indicate that discriminant validity is in considerable range to validate the constructs used in the study. 
Table 2. Assessment results of the measurement model

\begin{tabular}{|c|c|c|c|}
\hline Construct/ Associated Terms & Loading & Composite Reliability & Average Value Extracted \\
\hline Limited Time & & \multirow[t]{5}{*}{ 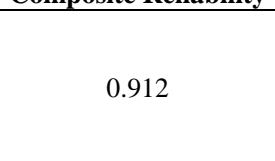 } & \multirow[t]{5}{*}{ 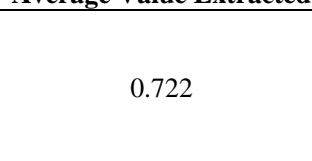 } \\
\hline LT1 & 0.876 & & \\
\hline LT2 & 0.889 & & \\
\hline LT3 & 0.857 & & \\
\hline LT4 & 0.772 & & \\
\hline \multicolumn{2}{|l|}{ Limited Communication } & \multirow{4}{*}{.889} & \multirow{4}{*}{.729} \\
\hline Communil & 0.920 & & \\
\hline Communi2 & 0.874 & & \\
\hline Communi3 & 0.758 & & \\
\hline \multicolumn{2}{|l|}{ Limited Involvement } & \multirow{3}{*}{0.950} & \multirow{3}{*}{0.904} \\
\hline LI1 & 0.951 & & \\
\hline LI2 & 0.951 & & \\
\hline \multicolumn{2}{|l|}{ Positive Holiday Mood } & \multirow{4}{*}{0.850} & \multirow{4}{*}{0.657} \\
\hline Mood1 & 0.887 & & \\
\hline Mood2 & 0.858 & & \\
\hline Mood3 & 0.669 & & \\
\hline \multicolumn{2}{|l|}{ Unfamiliarity } & \multirow{5}{*}{0.944} & \multirow{5}{*}{0.810} \\
\hline Unfami1 & 0.851 & & \\
\hline Unfami2 & 0.912 & & \\
\hline Unfami3 & 0.915 & & \\
\hline Unfami4 & 0.920 & & \\
\hline \multicolumn{2}{|l|}{ Overall Satisfaction } & \multirow{5}{*}{0.918} & \multirow{5}{*}{0.738} \\
\hline Satisfaction1 & 0.878 & & \\
\hline Satisfaction2 & 0.894 & & \\
\hline Satisfaction3 & 0.830 & & \\
\hline Satisfaction 4 & 0.832 & & \\
\hline
\end{tabular}

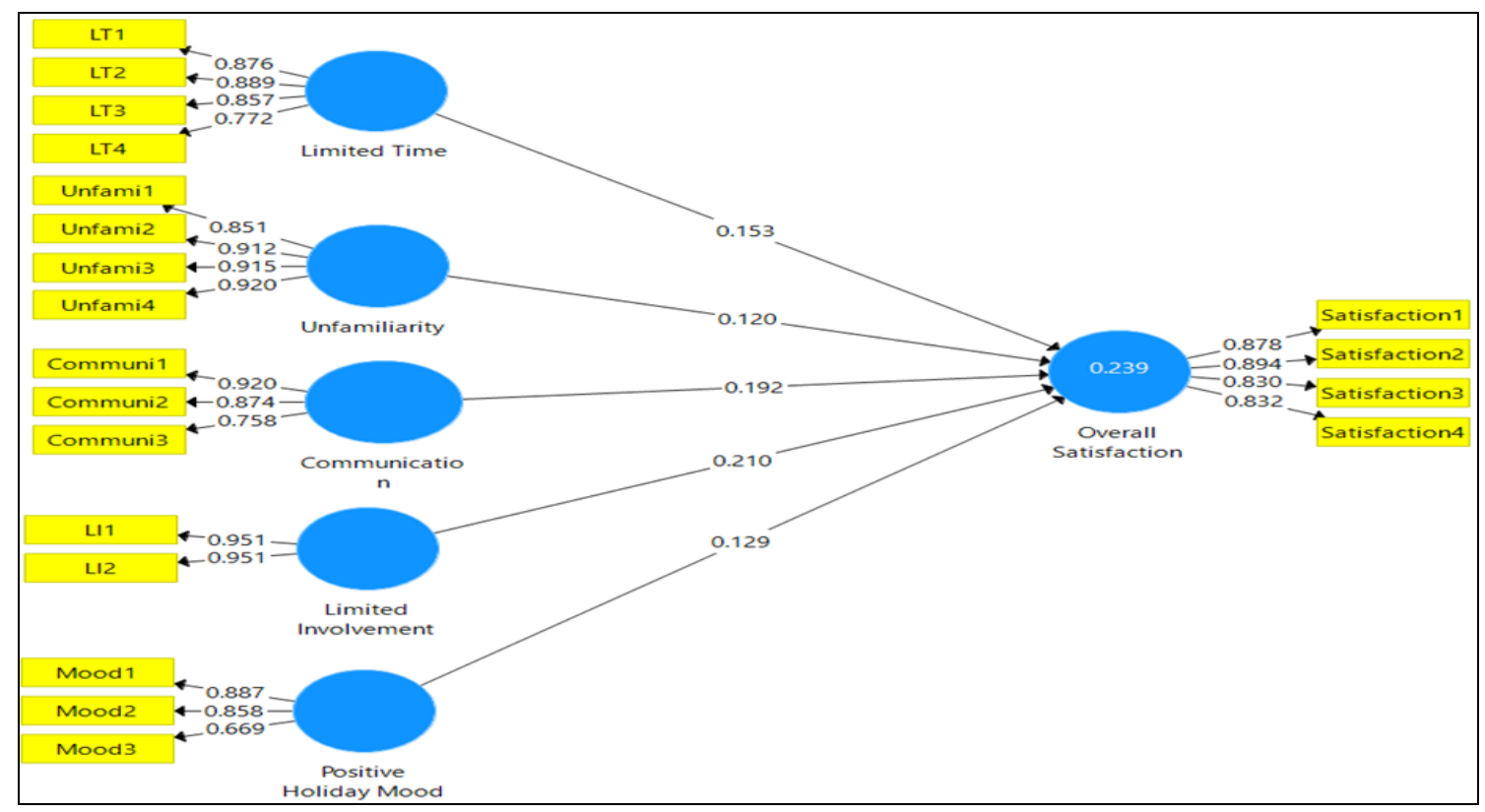

Figure 2. Measurement model of the study

Table 3. Discriminant Validity - Heterotrait-Monotrait Ratio (HTMT)

\begin{tabular}{|l|l|l|l|l|l|l|}
\hline & Communication & Intention & Limited Involvement & Limited Time & Positive Holiday Mood & Unfamiliarity \\
\hline Communication & & & & & \\
\hline Intention & 0.386 & & & & \\
\hline Limited Involvement & 0.340 & 0.401 & & & \\
\hline Limited Time & 0.190 & 0.255 & 0.103 & & \\
\hline Positive Holiday Mood & 0.142 & 0.263 & 0.199 & & \\
\hline Unfamiliarity & 0.351 & 0.352 & 0.524 & 0.094 & \\
\end{tabular}

Table 4. Discriminant Validity - Fornell - Larcker Criterion

\begin{tabular}{|l|l|l|l|l|l|l|}
\hline & Communication & Intention & Limited Involvement & Limited Time & Positive Holiday Mood & Unfamiliarity \\
\hline Communication & 0.854 & & & & \\
\hline Intention & 0.328 & 0.859 & & & \\
\hline Limited Involvement & 0.296 & 0.357 & 0.951 & & \\
\hline Limited Time & 0.164 & 0.229 & 0.092 & 0.850 & \\
\hline Positive Holiday Mood & 0.096 & 0.212 & 0.140 & 0.075 & \\
\hline Unfamiliarity & 0.308 & 0.326 & 0.482 & 0.134 & \\
\hline
\end{tabular}

Assessment of structural model of the study

The diagram in Figure 2 and Table 5 demonstrated the structural model of the study. T-values of the model are showing high efficiency in the construct. The influence of the independent variable to the dependent variable is positively significant. To find the direct effects, the 
bootstrapping method was performed in Smart PLS 3. The study examined the direct relationship of Limited time, unfamiliarity, limited communication, limited involvement, positive holiday mood with overall satisfaction of the domestic tourists in Malaysia.

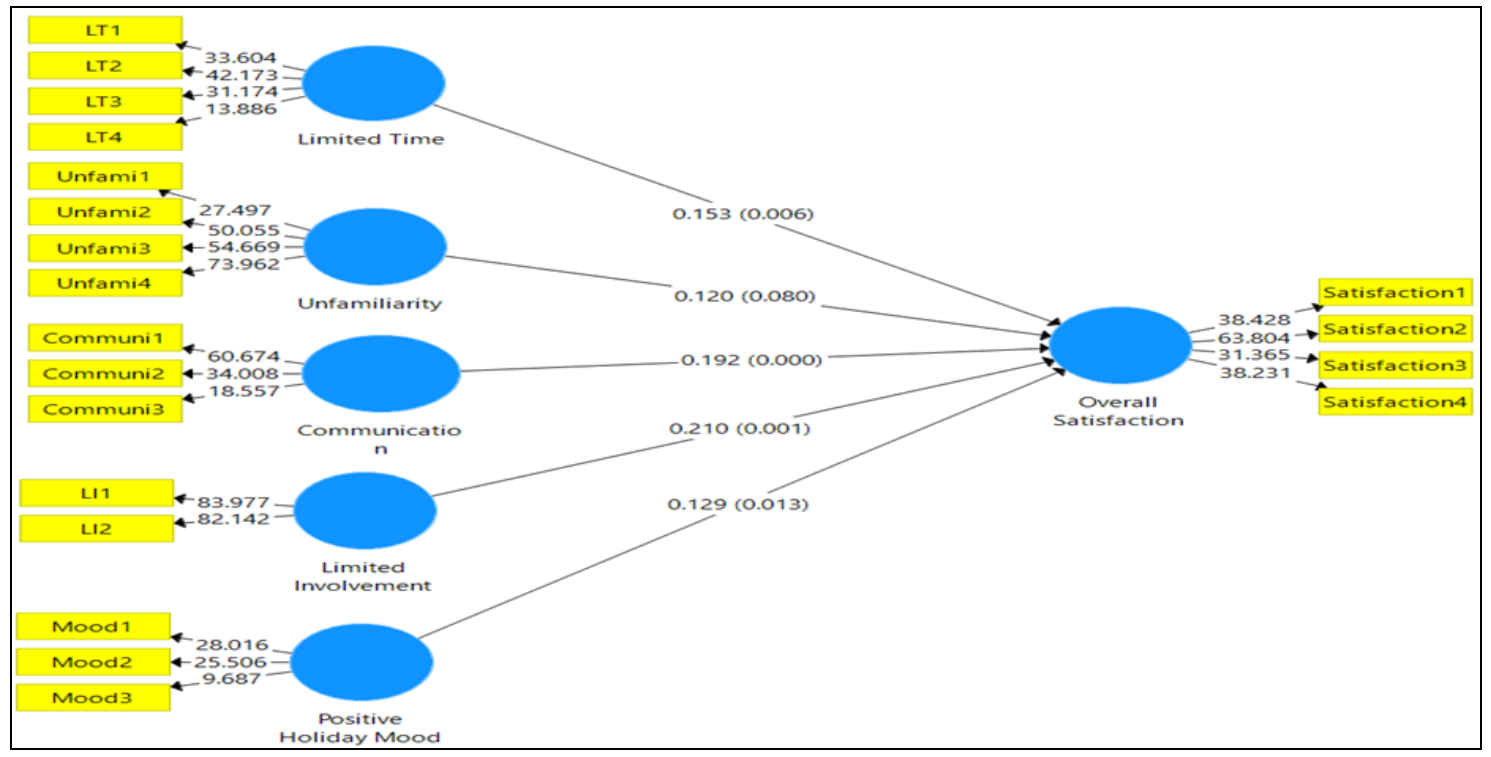

Figure 3. Structural model of the study

As shown in Table 5, the independent variables of this study limited time $(\mathrm{T}$ value $=3.034, \mathrm{p}$ value $=0.003)$, unfamiliarity $(\mathrm{T}$ value $=1.771, \mathrm{p}$ value $=0.077$, limited communication $(\mathrm{T}$ value $=3.786$, $\mathrm{p}$ value $=0.000)$, limited involvement $(\mathrm{T}$ value $=3.562$, $\mathrm{p}$ value $=0.000)$, and positive holiday mood $(\mathrm{T}$ value $=2.499$, $\mathrm{p}$ value $=0.000)$ have significant relationship with overall satisfaction of domestic tourists in Malaysia.

Table 5. Direct effects

\begin{tabular}{|c|c|c|c|c|c|}
\hline Hypothesis & Relationship & Path Coefficient & $\mathrm{t}$ Value & $\mathrm{P}$ values & Supported \\
\hline $\mathrm{H} 1$ & Limited Time $->$ Overall Satisfaction & 0.153 & 3.034 & 0.003 & $\sqrt{ }$ \\
\hline $\mathrm{H} 2$ & Unfamiliarity -> Overall Satisfaction & 0.120 & 1.771 & 0.077 & $\sqrt{ }$ \\
\hline H3 & Limited Communication -> Overall Satisfaction & 0.192 & 3.786 & 0.000 & $\sqrt{ }$ \\
\hline $\mathrm{H} 4$ & Limited Involvement $->$ Overall Satisfaction & 0.210 & 3.562 & 0.000 & $\sqrt{ }$ \\
\hline H5 & Positive Holiday Mood -> Overall Satisfaction & 0.129 & 2.499 & 0.013 & $\sqrt{ }$ \\
\hline
\end{tabular}

\section{DISCUSSION AND CONCLUSION}

The research revealed that tourists' complaint constraints ought to be taken into account as complaints from the tourists' present precious information regarding service quality problems, and it should be viewed as an opportunity to learn how to improve service. Although, the greatest hazard is not trying to bother to complain but rather essentially take away negative word-of-mouth publicity and business somewhere else. In this regards, Malaysian tourists are less expressive in their views and providing negative feedback could be considered as tongue-tied and complex (Ndubisi and Tam, 2007). This study also revealed that overall tourists' satisfaction of the domestic tourists is influenced by limited time, unfamiliarity, limited communication, limited involvement, and positive holiday mood. Most of the respondents who precise their reason for not complaining as Limited Time, reporting complain is time consuming and handling complaints by the service provider will take longer time in handling the complaints as the tourists used to have time limitation during their trip. The second most common reason for not complaining was Limited Communication. For that reason, hoteliers in Malaysia should not simply ignore any negative perception provided by consumers. Hoteliers should look to enhance the services and gain more knowledge about consumer complaint behaviours. More prompt and efficient consistent services to consumers will develop their customer service. A service provider should be able to learn from complaints, e.g. how to prevent similar mistakes or service failure in future and identify where and how these mistakes happened. So, hoteliers should welcome more complaints from tourists and take a step to make it easy for tourists to complain. Hoteliers should understand that no complaints from customers do not indicate a good customer's satisfaction level. In this regard, the organization must have the intuition to think any complaints positively to develop further but not to take directly as an act of conflict. To conclude, it is assumed that the research framework and information flow from this study will assist a better understanding of correspondent authorities. A better understanding of the tourists' complaint constraints (Limited Time, Unfamiliarity, Limited Communication, Limited Involvement and Positive Holiday Mood) in terms of hotel service will provide hoteliers with valuable information to increase their effectiveness in handling the operation, improving customer satisfaction and repeat patronization.

\section{REFERENCES}

Albrecht, K., \& Zemke, R. (1996). Service America! Doing Business in the New Economy. Homewood, IL, Dow Jones-Irwin.

Altinay, M. (1994). Kucuk ada ulke ekonomilerinde turizm. Eastern Mediterranean University Press, Famagusta. https://doi.org/10.1080/19368620903024959

Badghish, S., Stanton, J., \& Hu, J. (2015). An exploratory study of customer complaint behaviour (CCB) in Saudi Arabia. Asian Journal of Business Research, 2015, 49-67. https://doi.org/10.14707/ajbr.150004.

Baker, D.A., \& Crompton, J.L. (2000). Quality, satisfaction and behavioral intentions. Annals of tourism research, 27(3), 785-804. https://doi.org/ $10.1016 / \mathrm{S} 0160-7383(99) 00108-5$

Best, A., \& Andreasen, A.R. (1977). Consumer response to unsatisfactory purchases: a survey of perceiving defects, voicing complaints, and obtaining redress, Law \& Society Review, 11 (3), 701-742. https://doi.org/10.2307/3053179

Bhattacherjee, A. (2001). Understanding information systems continuance: an expectation-confirmation model. MIS Quarterly, 351-370. https://doi.org/10.2307/3250921

Biswas, C., Omar, H., \& Rashid-Radha, J.Z.R.R. (2020). The Impact of Tourist Attractions and Accessibility on Tourists' Satisfaction: The Moderating Role of Tourists' Age. Geojournal of Tourism and Geosites, 32(4), 1202-1208. https://doi.org/10.30892/gtg.32402-558 
Bloemer, J., Brijs, T., Swinnen, G., Vanhoof., K. (2002). Identifying latently dissatisfied customers and measures for dissatisfaction management, International Journal of Bank Marketing, 20 (1), 27 - 37. https://doi.org/10.1108/02652320210415962

Bonvillain, N. (2003). Language, culture, and communication - the meaning of messages (4th ed.), NJ, Prentice Hall.

Cai, L.A., Feng, R., \& Breiter, D. (2004). Tourist purchase decision involvement and information preferences. Journal of Vacation Marketing, 10(2), 138-148. https://doi.org/10.1177\%2F135676670401000204

Chebat, J.C., Davidow, M. \& Codjovi, I. (2005). Silent voices: Why some dissatisfied consumers fail to complain. Journal of Service Research, 7(4), 328-342. https://doi.org/10.1177\%2F1094670504273965

Christiansen, T., \& Snepenger, D.J. (2002). Is it the mood or the mall that encourages tourists to shop. Journal of Shopping Center Research, 9(1), 7-26. https://doi.org/10.1108/17506180710729628

Cohen, E. (2004). Contemporary tourism: Diversity and change. MA, Elsevier.

Crompton, J.L., \& Love, L.L. (1995). The predictive validity of alternative approaches to evaluating quality of a festival. Journal of travel research, 34(1), 1124. https://doi.org/10.1177\%2F004728759503400102

Crompton, R.L., \& Landon, E.L. (1976). Toward a Theory of Consumer Complaint Behavior: Consumer and Industrial Buying Behavior. North-Holland, New York, NY, 425-37. https://doi.org/10.1108/09604520710834966

Day, R.L. \& Landon, EL (Jr). (1977). Toward a theory of consumer complaining behavior. In Woodside, AG, Sheth, IN, Bennet, PD. Consumer and industrial buying behavior. North-Holland, New York. https://doi.org/10.1108/09604520710834966

Ekiz, E.H., \& Au, N. (2011). Comparing Chinese and American attitudes towards complaining. International Journal of Contemporary Hospitality Management, 23(3), 327-343. https://doi.org/10.1108/09596111111122514

Furlong, C. (1993). Marketing for: Building your Business by Retaining your Customers. John Wiley \& Sons, New York, NY.

Gronhaug, K., \& Zaltman, G. (1981). Complainers and noncomplainers revisited: Another look at the data. In K.B. Monroe (Eds.), Advances in Consumer Research, MI, Association for Consumer Research, 83-88.

Hassan, A.T, Biswas, C., Roy, M., Akter, S., \& Kuri, B.C. (2020). The Applicability of Theory of Planned Behaviour to Predict Domestic Tourist Behavioural Intention: The Case of Bangladesh. GeoJournal of Tourism and Geosites, 31(3), 1019-1026. https://doi.org/10.30892/gtg.33113-536

Havitz, M.E., \& Dimanche, F. (1999). Leisure involvement revisited: Drive properties and paradoxes. Journal of Leisure Research, 31(2), 122-149. https://doi.org/10.1080/00222216.1999.11949854

Hedrick, N., Beverland, M., \& Minahan, S. (2007). An exploration of relational customers'response to service failure. Journal of Services Marketing, 21(1), 64-72. https://doi.org/10.1108/08876040710726301

Hocutt, M.A., Chakraborty, G., \& Mowen, J.C. (1997). The art of service recovery: Fact or fiction? An empirical study of the effects of service recovery. Marketing Theory and Applications, 50-51. https://doi.org/11.123200/J061v04n0203

Hosany, S., \& Gilbert, D. (2010). Measuring tourists' emotional experiences toward hedonic holiday destinations. Journal of Travel Research, 49(A), 513526. https://doi.org/10.1177\%2F0047287509349267

Iso-Ahola, S.E. (1982). Toward a social psychological theory of tourism motivation: A rejoinder. Annals of Tourism Research, 12(1), 256-262. https://doi. org/10.1016/0160-7383(82)90049-4

Jamal, S.A., Othman, N.A., \& Muhammad, N.M.N. (2011). Tourist perceived value in a community-based homestay visit: An investigation into the functional and experiential aspect of value. Journal of Vacation Marketing, 17(1), 5-15. https://doi.org/10.1177\%2F1356766710391130

Kozak, M. (2001). Comparative assessment of tourist satisfaction with destinations across two nationalities. Tourism Management, 22(4), 391-401. https://doi.org/10.1016/S0261-5177(00)00064-9

Krejcie, R.V., \& Morgan, D.W. (1970). Determining sample size for research activities. Educational and Psychological Measurement, 30(1), 607-610. https://doi.org/10.1177\%2F001316447003000308

Laing, J., Wheeler, F., Reeves, K., \& Frost, W. (2014). Assessing the experiential value of heritage assets: A case study of a Chinese heritage precinct, Bendigo, Australia. Tourism Management, 40, 180-192. https://doi.org/10.1016/j.tourman.2013.06.004.

Lam, T., \& Tang, V. (2003). Recognizing Customer Complaint Behavior. Journal of Travel and Tourism Marketing, 14 (1), 69-86. https://doi.org/10.1300/J073v14n0105

Liljander, V., \& Mattsson, J. (2002). Impact of customer pre-consumption mood on the evaluation of employee behavior in service encounters. Psychology and Marketing, 79(10), 837-860. https://doi.org/10.1002/mar.10040

Maunier, C., \& Camelis, C. (2013). Toward an identification of elements contributing to satisfaction with the tourism experience. Journal of Vacation Marketing, 19(1), 19-39. https://doi.org/10.1177\%2F1356766712468733

Mittal, B., \& Lee, M.S. (1989). A causal model of consumer involvement. Journal of Economic Psychology, 10(3), 363-389. https://psycnet.apa.org/doi/ $10.1016 / 0167-4870(89) 90030-5$

Morello, G. (2004). Spacing and timing in leisure activities. In K. Weiermair\& C. Mathies (Eds.), The Tourism and Leisure Industry - Shaping the Future. NY, Haworth Hospitality Press, 69-81. https://doi.org/10.1007/978-1-349-19527-5 11

Ndubisi, N.O. \& Tam, Y.L. (2007). Evaluating gender differences in the complaint behavior of Malaysian consumers. Asian Academy of Management Journal, 12(2), 1-13. Available at http://hdl.handle.net/10072/59217

Nyer, P.U. (2000). An investigation into whether complaining can cause increased consumer satisfaction. Journal of consumer marketing, 17(1), 9-19. https://doi.org/10.1108/07363760010309500

Pearce, P.L. (1982). Tourists and their hosts: Some social and psychological effects of inter-cultural contact. In S. Bochner Eds, Cultures in Contact: Studies in Cross-cultural Interaction, OX: Pergamon Press, 199-221. Available at https://www.cabdirect.org/cabdirect/abstract/19831802770

Reisinger, Y., \& Turner, L.W. (2003). Cross-cultural behaviour in tourism: Concepts and analysis. Butterworth-Heinemann, Elsevier.

Richins, M.L. (1982). An investigation of consumers' attitudes toward complaining. ACR North American Advances. https://doi.org/112.132323/J061v04n02_03

Riddick, C.C., \& Russell, R.V. (1999). Evaluative research in recreation, park, and sport settings: Searching for useful information. Champaign, IL: Sagamore. https://doi.org/10.1016/S0969-6989(00)00007-2

Rust, R.T., \& Oliver, R.W. (1994). The death of advertising. Journal of Advertising, 23(4), 71-77. Available at https://www.jstor.org/stable/4188952

Schiffman, L.G., \& Kanuk, L.L. (2004). Consumer behavior. (8th ed.), NJ, Prentice-Hall International Inc.

Sharma, P., Marshall, R., Reday, P.A., \& Na, W. (2010). Complainers versus non-complainers: a multi-national investigation of individual and situational influences on customer complaint behavior. Journal of Marketing Management, 26(1-2), 163-180. https://doi.org/10.1080/02672570903512502

Soderlund, M. (2002). Customer familiarity and its effects on satisfaction and behavioral intentions. Psychology and Marketing, 79(10), 861-880. https://doi.org/10.1002/mar.10041

Stephens, N., \& Gwinner, K.P. (1998). Why don't some people complain? A cognitive dynamic process model of consumer complaint behavior. Journal of Academy of Marketing Science, 26(3), 172-189. https://doi.org/10.1177/0092070398263001

Su, W.Y., \& Bowen, J.T. (2001). Restaurant customer complaint behavior. Journal of Restaurant \& Foodservice Marketing, 4(2), 35-65. https://doi.org/ $10.1300 / \mathrm{J} 061 \mathrm{v} 04 \mathrm{n} 02 \_03$

Suvantola, J. (2002). Tourist's experience of place: New directions in tourism analysis. Hampshire: Ashgate Publishing Ltd.

Swanson, S.R., \& Kelly, S.W. (2001). Service recovery attributions and word-of-mouth intentions. European Journal of Marketing, 35(1/2), 194-211. https://doi.org/10.1108/03090560110363463

Treisman, M. (2013). The information-processing model of timing (Treisman, 1963): its sources and further history. Timing Time Percept, 1(2), 131-158. https://doi.org/10.1163/22134468-00002017

Van der Knaap, W. (1997). The tourist drives - GIS oriented methods for analysing tourist recreation complexes. Landbouwuniversiteit te Wageningen, The Netherlands. https://doi.org/10.1080/14616689721294

Voase, R. (1995). Tourism: The human perspective. LD: Hodder\& Stoughton.

Wood, K., \& House, S. (1991). The good tourist: A worldwide guide for the green traveler. LD, Mandarin.

Yiannakis, A., \& Gibson, H. (1992). Roles tourists play. Annals of Tourism Research, 19(2), 287-303. https://doi.org/10.1016/0160-7383(92)90082-Z

*** Technical Assistance Research Programme (TARP) (1981). Measuring the Grapevine: Consumer Response and Word-of-Mouth, Coca-Cola, Atlanta, GA. 